\title{
Social work and social problems: A contribution from systems theory and constructionism
}

\author{
Dimitris Michailakis and Werner Schirmer
}

\section{Linköping University Post Print}

\section{Tweet}

N.B.: When citing this work, cite the original article.

Original Publication:

Dimitris Michailakis and Werner Schirmer, Social work and social problems: A contribution from systems theory and constructionism, 2014, International Journal of Social Welfare, (23), 4, 431-442.

http://dx.doi.org/10.1111/ijsw.12091

(C) 2014 The Author(s). International Journal of Social Welfare. (c) 2014 International Journal of Social Welfare and John Wiley \& Sons Ltd

http://onlinelibrary.wiley.com/

Postprint available at: Linköping University Electronic Press

http://urn.kb.se/resolve?urn=urn:nbn:se:liu:diva-107377 


\title{
Social work and social problems: A contribution from systems theory and constructionism
}

(Published in International Journal of Social Welfare, 23 (4), pp. 431-442)

\author{
Prof Dimitris Michailakis \\ TEFSA - Platform for Theory-driven Research in Social Work \\ Department of Social and Welfare Studies \\ University of Linköping/Sweden \\ dimitris.michailakis@liu.se
}

\author{
Associate Prof Werner Schirmer \\ TEFSA - Platform for Theory-driven Research in Social Work \\ Department of Social and Welfare Studies \\ University of Linköping/Sweden \\ werner.schirmer@liu.se
}

\begin{abstract}
Social work builds its identity on social problems. The goal is to generate knowledge about causes, consequences and solutions. We suggest that research on social problems can benefit by 'bringing the observer in': Loseke's constructionist framework and Luhmann's systems theory. According to Loseke, social problems appear differently when constructed by different observers. Constructions vary in terms of morality, conditions, victims/villains, and solutions. From Luhmann we learn that modern society consists of a multitude of social systems (e.g. politics, science, economy etc.) each operating with their own communicative codes. Combining both approaches, we hypothesize that any social system constructs its own (version of) social problems. Illustrating with the empirical case 'suicide among mentally ill people' we examine how a phenomenon is constructed differently as a social problem by four different social systems: the disability movement, politics, medicine and social work.
\end{abstract}

\section{Key words:}

social problems, systems theory, constructionism, suicide, social work theory, Luhmann 


\section{Introduction}

The academic discipline social work builds its identity on the study of social problems. The goal is to generate knowledge about causes, consequences and potential solutions for social problems. This knowledge is expected to be useful to practitioners working with clients affected by different adverse conditions. In empirical social work research on poverty, discrimination, social exclusion, homelessness, juvenile delinquency, domestic violence and human trafficking, it is usually taken for granted what the 'social problem' is. The social problem is treated as a deplorable circumstance "about which something must be done" (Holstein \& Miller, 1993a). It is therefore considered to be a deviation from a desirable condition (how society ought to be), how exposed groups suffer from these conditions (Gould \& Baldwin, 2004; Healy \& Link, 2012; Korpi, Nelson, \& Stenberg, 2007; Payne, 2005b; Trevithick, 2007) and what social work practitioners need to take into consideration when dealing with those bearing the symptoms of such conditions.

What this kind of research has in common is that it addresses 'what' questions (what is a social problem, what solutions are there for social problem Y), which makes it basically essentialist, since it looks for the 'essence' of social problems or the objective conditions that cause, trigger or sustain them. Social problems appear to be natural incidents which seem to exist independently of social relations, context, time or observer (Fuchs, 2001, p.13). In our view the essentialist stance is an obstacle to theory development (see Spector \& Kitsuse, 1987 [1977]). We suggest that there is considerable potential for the development of a theory of social problems in social work once a re-orientation is made from 'what' questions to nonessentialist 'how' questions. 'How' questions do not ask about the nature of social problems but about how the very problems are shaped and applied differently by different observers. Hence, the move we suggest is from the level of essentialist observations to constructionist observations, i.e. the observation of observations made by different observers (Fuchs, 2001, p.27; Luhmann, 1990).

We argue that social problems are what communication theorist Paul Watzlawick called second-order realities (Watzlawick, 1984). The distinction between first- and secondorder reality is helpful in clarifying a common mistake and separating essences and constructions. ${ }^{1}$ First-order reality refers to physical characteristics and qualities of a thing, event or situation. First-order reality consists of uninterpreted facts that are accessible (i.e., in the world), measurable and empirically verifiable. This is the world of facts. Examples are temperatures, sounds, cities, buildings or the number of human beings in a social situation. Second-order reality includes any descriptions (and thus interpretations) of the first-order reality. This is the world of meaning. Second-order realities are created whenever we attribute meaning to a first-order reality. Meaning is not to be found 'in' the facts. Whether certain temperatures are considered just and reasonable, sounds noisy or musical, cities car-friendly or aesthetic, buildings used as schools, hospitals or barracks, or human beings in a social situation considered as agentive interlocutors or bodies is always a matter of interpretation, and thus a second-order reality on the basis of the first-order reality. These interpretations as

\footnotetext{
${ }^{1}$ This distinction is not to be confused with the distinction between first- and second-order observation as developed by von Foerster and Luhmann.
} 
they appear in descriptions include observers' opinions, judgments, assessments, evaluations and accounts. Different observers interpret the same first-order reality in various ways.

When something - an adverse condition, a gap between expectations and how things are etc. - is described as a social problem, we must therefore look not only at the facts of the problem described but also at the description itself, and that leads us to the observer behind the description: from what perspective is s/he observing, what positions and what interests are involved? As we will show in the course of this article, these are not simply considerations for the philosophical ivory tower but have considerable relevance, both empirically for social work researchers and practically for social work practitioners. As Fuchs notes, the 'important conflicts in modern societies...concern who is an observer, what this observer can and cannot see, and how significant or binding his observations are for other observers' (Fuchs, 2001, p.20). Approaches to social problems that fail to account for the observers can be instrumentalised by welfare bureaucracies by defining people as deviant and as a target for interventions, thereby turning social work into an issue of power (Mik-Meyer \& Villadsen, 2013).

Modern societies are characterized by high levels of pluralisation and differentiation of classes, milieus, subcultures and minority cultures, and other groups. For this reason, one cannot simply assume that all agents involved in a certain social problem have the same understanding of it in terms of definition, conditions, remedies etc. Even if they agree that, for instance, social inequality poses a social problem, there is no consensus on what exactly determines the problem and even less on its causes and solutions: is it an unfair distribution of wealth and access to resources; is it the result of a lack of incentives or individual initiative? Are those in powerful positions responsible, the collective or the individual? Depending on who observes the problem, their moralities, interests and many other factors, the answers will look different. The plurality of observers implies a potential plurality of observations and accompanying descriptions. Hence, assessments of something as a "social problem" do not reveal objective conditions. Problems are problems always and without exception from a particular point of view; they become part of society always as observations and descriptions from a particular observer.

The empirical question is to what extent and in what dimensions/parameters the definitions of problem constructions vary. The overarching research agenda we want to suggest in this article is: How do different agents construct the (same) social problem differently? Our article aims to present a theoretical synthesis of two approaches which, in their combination, offer a useful theoretical as well as methodological tool to study social problems in a non-essentialist manner, that is, as second-order realities. The combination allows us to focus on the very observers who construct something as a social problem and to pinpoint the societal locus from which these observers make their claims. The two approaches are constructionism in social problems research and Luhmann's theory of functionally differentiated society. The article is structured as follows: the second section presents constructionist approaches to social problems with regard to four parameters along which constructions of social problems may vary: moral values, causal explanations, victims and responsible actors, and solutions. The third section discusses the Luhmannian theory of society social systems, in particular protest movements, the function systems of politics, science and medicine. In the fourth section, we argue for a theory synthesis of the approaches presented in the second and third sections. The fifth section offers an outline of the 
synthesized approach to studying social problems with the help of an illustrative empirical case: suicide among mentally ill people as a social problem. The final section (sixth) offers some implications for research in social work dealing with social problems.

\section{Constructionist approaches to social problems}

Constructionism is not an uncommon approach in social work research (see Payne, 1999). It plays a prominent role in studying the labeling and social categorisation of client groups with so-called problematic identities (criminals, substance abusers, refugees, immigrants, victims etc.). Other typical cases of constructionism in social work are the analysis of discursive power orders (between ethnic majorities and minorities, insiders and outsiders, social workers and clients) and gender norms. What this kind of research has in common is that the very portrayal of a group as problematic, afflicted or troublesome is deemed the root of the social problem while the problem (e.g. inequality, drug abuse, domestic violence) itself is taken as a given. In this regard, the social problem is the blind spot of social work observers.

By contrast, constructionist approaches in social problems research focus on the construction of the social problem itself. Their points of departure are the questions of how and why some (but not other) conditions have received the status of social problem (Holstein \& Miller, 1993b; Loseke, 2003; Loseke \& Best, 2011; Spector \& Kitsuse, 1987 [1977]). A follow-up question is why a particular condition is sometimes seen as a problem and sometimes as a solution. Constructionists argue that essentialist approaches cannot understand and explain why some (seemingly) harmful social conditions are given the status of social problems while others are not. Constructionists go even further and question the very basis of objectivist approaches, i.e. the assumption that social problems can be studied as measurable deviances from desired normative standards. The theoretical and methodological problem is how to define those standards, whose standards they are, when and why are they desired, by how many etc. (Spector \& Kitsuse, 1987 [1977], p.31ff).

According to constructionism, a problem does not exist socially before it has been defined by some agent as a social problem. While social conditions unfavourable to some groups might exist, these do not pose a social problem before they have been defined as problematic and needing solutions (Loseke, 2003, p.14). Hence, social problems are considered the result of an activity undertaken by so-called 'claims-makers' (Spector \& Kitsuse, 1987 [1977]), for example social movements, politicians or concerned scientists. Claims-makers raise the claim that some, in their view, adverse condition receives the status of a social problem, thus as an undesirable but existent social condition that violates ethical standards or other widely shared values, afflicts certain groups and requires countermeasures.

According to Donileen Loseke (2003), the constructions of a given condition as a social problem can vary in the following parameters:

Conditions and causal relations: claims-makers construct the conditions of the projected problem, thus what is wrong (and needs to be corrected), what is part of the problem (and what is not), what is the cause of the problem and who is responsible. This parameter of social problems construction corresponds in part to what Snow \& Benford mean by 'diagnostic framing'(Snow \& Benford, 1988; see also: Jönson, 2010).

Cultural themes: constructions make use of an underlying morality; the problem is constructed as a condition that violates/breaks with generally accepted (culturally and 
historically specific) values and provokes indignation. Variation in cultural themes corresponds to what Snow \& Benford mean by 'motivational framing' (Snow \& Benford, 1988).

People: on the one hand, there are victims of the putative condition who deserve sympathy, who are not responsible and unfairly affected. On the other hand, there are villains who deserve condemnation; they can be but do not need to be individuals, groups, a system, an institution, social forces or social structures.

Solutions: construction of a general line of action (what ought to be done) and responsibility (who should do it). These claims legitimate certain solutions (and exclude others) as well as construct indicators of success. Variation in solutions corresponds to what Snow \& Benford mean by 'prognostic framing' (Snow \& Benford, 1988).

\section{Luhmann's theory of functionally differentiated society}

The other theoretical pillar of this article is the theory of social systems by the sociologist Niklas Luhmann. The Luhmannian approach has already gained some prominence in social work, although mainly in a German (Baecker, 1994; Bommes \& Scherr, 2000; Merten, 2000) and Scandinavian context (Appel Nissen, 2010; La Cour, 2002; Moe, 2003); publications in international journals are still rather scarce (Author, 2013; Scherr, 1999; Villadsen, 2008; Wirth, 2009). Particular attention has been directed at the study of the function of organized social help and its relation to society. The Luhmannian theory is very complex and consists of several sub-theories (such as communication theory, theory of society, theory of organization). For the purpose of the present article, we will concentrate on a central aspect of Luhmannian theory, that is, the theory of functionally differentiated society.

According to Luhmann, modern society consists of a number of differentiated social systems which each fulfill a function for society (Luhmann, 1982, 1997). Examples are the systems of politics, economy, science, medicine, religion, law etc. Each of these function systems provides a solution to a specific societal reference-problem; they observe society from their own, function-specific perspectives and communicate whatever falls within their scope in a specific way. Function systems can only see what their unique perspective allows them to see. They are blind and indifferent to everything else. Because some systems will be discussed in more detail below, two brief examples should suffice for now: in the economic system everything appears as a commodity with a specific price. In the system of law, everything is observed in terms of legality: is it consistent with the laws in effect or does it violate them?

The theory of functional differentiation is a powerful analytic tool to examine many issues in modern societies in terms of horizontal differentiation; however, it needs to be complemented with another line of social differentiation, namely the differentiation of levels of social systems. We need to distinguish society (the level of function systems), organizations (parties, churches, corporations, schools), face-to-face interactions, networks and protest movements (Fuchs, 2001; Luhmann, 1982, 1997).

Combining functional differentiation with the differentiation of system levels helps us to analyze different constructions of social problems. Because the empirical focus of this article is on the topic of the suicide of mentally ill people as a social problem, the following paragraphs deal with one particular type of system, namely social movements (the disability 
movement of people with mental illness) as well as the three function systems of politics (the Swedish welfare state), science (social work) and medicine. The political system is of interest because it plays a key role in social problem construction: it is the receiver of claims made by the disability movement, it is the contracting body for social work and it is responsible for policy-making (Author, 2007). The system of science is of interest because social work is first and foremost a scientific discipline. Finally, since suicide is often seen a problem of illness, we also look at the perspective of the medical system.

\section{Social movements}

On the basis of Luhmannian differentiation theory, we can assume that the disability movement (and the faction representing disability due to mental illness) is a social system of its own type. Social movements mostly make use of the communication form of 'protest', that is, communication that criticises social conditions and tries to gain influence beyond institutions within the center of the political system (Luhmann, 1997, pp. 847-865). Protest communication divides society into two groups: those who protest against and are affected by existing social conditions, on the one hand, and those the protest is directed against, i.e. those who represent, profit from or refuse to change the social conditions, on the other hand. In order to mobilise support and loyalty, protest communication invokes ethical principles which according to the self-image of a social movement are morally superior to the ethics of its opponents. Therefore, protest communication is prone to point out injustices and violations of prevailing values. Another characteristic of protest movements is the frequent use of simplified causality both in terms of sources of the problematic condition and its solutions. The reference object of the protest is seen as a result of causes that are external to the movement, portrayed as objective, essential and impossible to reject. Therefore, a movement generates expectations of countermeasures by others (mostly the political system) and demands solutions to problems identified without having to worry about the very consequences the solutions demanded lead to (Luhmann, 1997, p.855) ${ }^{2}$. For a social movement (such as the disability movement), the point of departure for the construction of social problems lies in highlighting the putative problem as a violation of prevailing values, thereby generating collective support and forcing the addressee to undertake measures.

\section{Politics}

The system of politics and its organizations (such as parties, government, parliament) mostly makes use of power-based communication (Luhmann, 2000). The function of politics is to

\footnotetext{
${ }^{2}$ Readers might be reminded of the idea of "moral panic" as developed by Cohen (2002[1972]) as well as Goode and Ben-Yehuda (2009). Similarities cover the breach of existing values, the construction of victims and villains and a simplified causality. However, in contrast to protest movements whose protest aims at the social problem, thus social conditions adverse to value standards, moral panic focuses at a group deemed anti-social, i.e. an outgroup constructed as "folk devils". The other important difference is that the protest movement represents the minority criticizing social mainstream while moral panics rather represent the mainstream criticizing deviant groups, in other words: victims and villains are diametrically opposite.
} 
provide collectively binding decisions. This formula refers to decisions of governmental and administrative authorities which are binding for citizens (e.g. legislation). Even if the implementation of such decisions requires a power-based infrastructure (Willke, 1992), the political system in the capacity of a modern welfare state depends on legitimacy granted by the public and collective support (Author, 2012). Political communication is therefore always at least implicitly aimed at (and sensitive to) public opinion. As a welfare state, the political system bears general responsibility for collective goods such as security, infrastructure, healthcare and education. The state is accountable for policy-making and therefore is the main recipient of demands brought forward by protest movements. Therefore political selfdescriptions are typically aimed at conveying the welfare state's readiness and capability to take action in addressing and solving social problems. The political system can therefore be expected to construct social problems in a way that it can demonstrate power of action and competence.

\section{Science (social work)}

Social work is a discipline in the system of science. ${ }^{3}$ The societal function of science is to produce knowledge (Luhmann, 1990) that is reliable and can be used with surplus value in social contexts beyond science. In the case of social work, the primary 'consumers' of knowledge are social work practitioners, and the beneficiaries are the clients. In order to achieve reliability of the knowledge produced, certain quality criteria are required - precise concepts as well as methodological and theoretical rigor which can ensure that the research results accord with the truth. In other words, there are more or less clear rules for scrutinizing the validity (or falsity) of any scientific claim. This is the crucial difference between the communication forms of the two systems described above (movements, politics) and scientific communication. Of course, scholars are aware that this is an ideal to strive for. In reality, it is an empirical question how politicised a certain discipline is, that is, to what extent political or ideological ideas gain priority (even if hidden) over scientific truth. It is crucial to the identity of the discipline of social work that it can be seen as autonomous, i.e. a constructor of social problems in its own right or not. The more it is oriented towards scientificity, and thus towards truthfulness (in contrast to appropriateness, advantageousness, desirability), the more the constructions of social problems by social work (as an academic discipline) need to correspond to complex causality, value neutrality and an open-mindedness to unexpected results.

\section{Medicine}

The medical system is centered on communication about health and illness (Luhmann, 2005). In the context of medical communication, human beings become relevant as bodies (Saake, 2003), and only if their condition can be related to symptoms for diagnoses of illness (Author,

\footnotetext{
${ }^{3}$ Social work is, of course, the unity of practice, professional ethos and research. However, in this article, we focus on social work as a scientific discipline which, then, is more exposed to the imperatives of the scientific system (such as publication practice) than functionality in practical intervention.
} 
2008, 2010). Medical observations scan human beings for pathological deviations from defined normal (healthy) states on biological, physiological, psychological or behavioural levels. With the exception of epidemiology, the focus of medicine (examination and treatment) is normally on the individual. However, medical communication involves not only treatment of current illness but also prevention of potential future illness on a collective level. That is where we can expect social problem constructions by the medical system - for instance, if a certain illness or other medically relevant pathological deviation occurs too often (measured by contingent standards) or if medicine is hampered by external (i.e., financial, political, legal) constraints in executing its function (Author, 2011). This also suggests that social problems constructed by the medical system can be expected to have a clear reference to illness, ways to treat the illness, and limits of the medical system's capacities due to (external) societal causes. ${ }^{4}$

\section{Combining constructionist social problems research and functional differentiation}

Mainstream research on social problems is under-theorized; researchers in social work have used the concept 'social problems' without relating it to a theory of the broader social context within which social problems emerge and are sustained. Without such a theory, there is an imminent risk that social problems researchers either adopt political or common sense definitions of the phenomena they investigate or lapse into subjectivism (Gould \& Baldwin, 2004; Healy \& Link, 2012).

We suggest a combination of the constructionist approach to social problems based on Spector \& Kitsuse's and Loseke's work as well as Luhmann's theory of functional differentiation. The constructionist approach provides a useful method for the empirical study of social problems as claims-making activity. However, this approach is not complete, and thus, has not been without criticism. With their seminal 1977 book, Spector and Kitsuse paved the way toward abandoning the search for objective conditions behind social problems and only look for claims-making activities - this was a reaction to the inconsistency problems any essentialist approach on social problems faced before them (especially Merton \& Nisbet, 1971 and Fuller \& Myers, 1941; see also Rubington \& Weinberg, 2010). Some years later, Woolgar and Pawluch (1985) accused many constructionists working with the Spector/Kitsuse-approach of "ontological gerrymandering", thus they claimed that through the backdoor, some objective conditions had sneaked into constructionism which indicated methodological inconsistencies in an approach that was understood as a remedy to those very

\footnotetext{
${ }^{4}$ We have now presented how the different social systems can be expected to construct social problems according to their own functions and codes and thus differently. That said, we need to note that movements, the systems of politics and medicine, and the discipline of social work are also differentiated internally. There are, for instance, different strands of disability associations with different goals. Within the political system, there are parties; parliaments can follow different rationalities than the government or the opposition (see Luhmann, 2000). There are different schools, specialisations and scholarly opinions in medicine as well as in social work (Payne, 2005a; Staub-Bernasconi, 2010). However, all subsystems in the same comprising system share the overarching modes of communication and observation of this comprising system.
} 
inconsistencies. As a compromise, Joel Best proposed a differentiation of strict and contextual constructivism (Best, 1989), the latter carefully taking into account objective conditions in the context of claims making, while still studying social problems as an activity of meaning production - thus constructionist. Ibarra and Kitsuse (1993) replied in a programmatic article to the faced criticism. While offering smaller adjustments to the original Spector/Kitsuseapproach, they made a clear statement for the strict constructionist paradigm (see also Troyer's critique of contextual constructionism, 1992). During the last decades, there have been repeatedly claims to go "beyond" constructivism (see only Hazelrigg, 1986) which meant to re-focus on "realist" components of social problems, for example in line with critical realism based on Bhaskar's work (Danermark, Ekström, Jakobsen, \& Karlsson, 2002; Houston, 2001).

When interested only in the objective conditions behind social problems, this might be a useful strategy. However, the reason why we see that social constructionism needs to be complemented is its lack of connection to a general framework of a theory of society that can account for societal reasons why certain observers tend to use certain distinctions and constructions, while other observers construct the problems differently.

Luhmann's theory, on the other hand, has no specialization in the study of social problems (despite the work by Hellmann, 1994). Still, it offers a precise conceptual apparatus for comprehending the highly specialized forms of system formation that characterise contemporary society. It is this functionally differentiated social structure that creates the special conditions for social problems in terms of definition, prevention, confrontation and solution. In the combination of both approaches we suggest here, we can explain how problems emerge in communication and what role social systems play, because this can link them with how the modern world has evolved and relate them to the function of the different systems. With Loseke, we can analyse claims-making activity, thus the construction of social problems, as a variation in the four parameters conditions and causal relations, cultural themes, people, and solutions. Luhmann provides the theory of society which can pinpoint how different observers differ systematically with their accounts of the social problem in focus. Variations in Loseke's parameters can then be interpreted as outcomes of the observational incompatibilities of the involved social systems. In the next section, we will illustrate how different social systems observe differently and how the constructions made by different observers vary in the parameters and along the lines of system-boundaries.

One note of caution: By suggesting the presented approach, we do not claim that social problems should not (or never) be studied in an essentialist way, i.e. searching for and explaining objective conditions. What we do, however, is point out what can be missed if one fails to take note of the insights a constructionist approach can offer, namely accounting for the empirical fact that different observers construct the same problem differently. By this we do not claim that this "same problem" is an objective condition either (thus no ontological gerrymandering) because we remain on the level of second order observation, simply taking seriously the observation of others: they seem to know that there "is" something, and that is reason enough for us study their accounts.

\section{Illustrative example: suicide as a social problem}


Suicide has been a source of inquiry by the social sciences particularly since Durkheim's famous study (Durkheim, 1979). Durkheim's major contribution was the focus on suicide as a social fact, i.e. to consider suicide as a social, not an individual matter. Thanks to Durkheim's work, suicide has begun to be seen as a social problem, which gives rise to preventive initiatives and efforts by many different agents and institutions, such as the welfare state, social workers and psychiatry. This is the background to why we use the phenomenon suicide among mentally ill people to illustrate the variation in constructions of a (given) social problem in different social systems.

In this section we present excerpts from different texts to illustrate the variation in constructions of suicide as a social problem along the lines of three function systems and one protest movement. ${ }^{5}$ The excerpts are from spokespeople of the different social systems discussed in section 3. We begin with two excerpts from the member journal of the Swedish National Association of Social and Mental Health (RSMH), a protest organisation that is part of the Swedish disability movement. Then we proceed with two excerpts from documents of the political system, a Swedish Government Official Report and a Government Bill. The third pair of excerpts comes from scientific articles in social work. Finally, we present a pair of excerpts from the journal of the Swedish Medical Association (Läkartidningen). Each pair of excerpts is followed by a short analysis according to the parameters presented in section 2 (conditions and causal relations, cultural themes/moralities, people and solutions). At the end of this section, we briefly discuss commonalities and differences in the constructions of suicide as a social problem in all social systems.

\section{Constructions of suicide as a social problem: protest movement}

\section{Excerpt 1: 'Scary statistics' from the Chairman of the RSMH}

Over the past few years, suicide in healthcare has been continuously on the rise .... an increase of almost 30 per cent within the last four years. It is not news to us at the RSMH, and our youth organisation RUS, that many children, teens and young adults are feeling worse than ever. There are also many reasons for this. As for the youngest, we know that there are major problems at school; classes are getting bigger and bigger while the staff are getting smaller and smaller. The school health services are cutting their activities and in many places there are neither school welfare officers nor school psychologists available in the first place ... Suicide is a problem that requires extremely powerful measures. We at the RSMH find that the government must begin to work immediately and pro-actively towards a vision zero of suicide which they in fact announced in 2008... (Trevett, 2011)

Excerpt 2: 'How is it possible to take one's life in an in-patient care department?' from the Business Co-ordinator of the RUS (youth organization of the RMSH)

Many suicide attempts are a cry for help - help that in many cases one does not get in today's psychiatry. I myself have been suicidal and not received the help I needed then, and I have many friends who told me about having the same problem. If one is hospitalized, the help

\footnotetext{
${ }^{5}$ The material was taken from an empirical study whose results are to be published elsewhere. That study investigates in a systematic way how different agents construct suicide among mentally ill people differently as a social problem.
} 
mostly consists of masses of drugs or electroshock treatment. I do not believe that this can be called good care. As I see it, there is also a need for contact or some kind of therapy treatment. More money must be allocated for this! I knew someone who was forced to take lots of drugs and she said she felt even more depressed by the medication and its side-effects. She could not stay in the psychiatry ward because there were no places available. When she came home, she killed herself. A life was erased because there was no room for her at the psychiatric clinic. More money needs to be allocated! ... We must together make demands on the government so that it also spends more money for research on suicide. We have no time to lose since there is a risk that even more people will commit suicide. Allocate money for this and do it now! (Andersson, 2010)

In both examples, suicide is constructed as a social problem, particularly when it concerns young people. The main condition for the problem in the first excerpt is the rise in suicide rates among young people over the past few years despite the government's promise to achieve the opposite. The second excerpt locates the problem in the quality and availability of mental care. As is typical of protest communication, in both excerpts there is an almost complete identification with the victims, either as members of the movement (excerpt 2) or as people represented by the movement (excerpt 1). The causes of the social problem are attributed to the environment of the movement (and its members), such as the school or medical care. Although an obvious reference to villains is absent, there is a straightforward appeal to the government as agent to be accountable in a double sense: not only has it been unable to avoid the problem (in the first excerpt, it is portrayed as a failure, unable to keep its own promises); the government is also expected to solve the problem. The solutions suggested, which are connected to the designation of the government as problem-solver, seem rather diffuse and simple (forceful measures, more money). However, it is not the function of protest communication to solve, but rather to highlight and complain about the existence of social problems.

\section{Constructions of suicide by politics}

Excerpt 3: 'Swedish Government Official Report 2010:45: Event analyses of suicides in healthcare and social service'

[T] he government notes that the vast number of suicides and attempted suicides as well as the enormous socio-economic costs and the mental suffering this causes implies that suicide ideation, attempted suicides and suicide in general constitute a major social problem. Suicide is seen as the final step in a long or short process in which biological, social, psychological and existential factors interact. Furthermore, the government notes that effective suicide prevention is based on the insight that suicide can be prevented. Suicide prevention requires broad cooperation and coordination that transcend sectors between local, regional and national agents. The need for systems thinking is emphasized and advised - as in other fields of injury prevention; the chain of events preceding a suicide should be examined through events analysis. Lessons can be learned from such analyses that can reduce the risk that a lack of availability or procedures, negligence or a lack of knowledge will be a contributing factor in suicide. (SOU [Swedish Government Official Reports], 2010, p. 26) 
There are no simple solutions for how to avoid suicide, but it is important that this observation does not paralyze but instead motivates people to find solutions and leads to an understanding about the life situations of young people.... There is an overarching vision in Sweden that nobody should be in such a precarious position that the only way out is perceived to be taking one's life. The government has the vision that nobody should have to take his/her life. To ensure that this vision is translated into constructive work in practice, there is a need for a national strategy designed with an appeal to Sweden's municipalities to develop local action plans. (Carlsson, 2012)

There is consensus between these two excerpts and the previous excerpts by the protest movement that the victims of the social problem are suicidal people themselves. In contrast to protest communication, however, the focus in these examples of political communication is more on complex causal factors both in terms of the causes of suicide as a social problem and the solutions (aimed at the design of social measures) to prevent the problem. Another striking contrast between political and protest communication is the role of the own agency. Whereas protest communication describes itself as a non-agent, i.e. an assembly of or representation for victims, political communication emphasizes its own ability to act by taking various measures. This is true even if the causes of the problem lie somewhere outside political action frames, for example biological or psychological factors. Suicide can be prevented, it says, so the government takes preventive action. The mentioning of a strategy (excerpt 4) again underscores the assumption that the government knows, despite the causal complexity, exactly what needs to be done. The solutions proposed are typically of a bureaucratic nature (more cooperation, more coordination, more action plans, more commissioned investigations, i.e. transferring the responsibility to act).

\section{Constructions of suicide by social work}

\section{Excerpt 5: 'Young People, Gender and Suicide'}

...[A]lmost all adolescents dying by suicide show evidence of suffering from some form of mood disorder.... XX argues that while suicide and depression are clearly linked, it is difficult to ascertain whether depression causes or is caused by suicidal thoughts and feeling.... it is not possible to determine whether they are a symptom or a cause of suicidal behavior. ...YY reported that a third of the under-25s who killed themselves were suffering from schizophrenia, whilst a fifth were given the primary diagnosis of personality disorder. In addition, they found that most people with schizophrenia were both unemployed and unmarried, with younger suicides also being more likely to have a history of substance or alcohol abuse and violence.... Although there is a clear link between mental health/illness and suicide risk, the relationship is a complex one. (Smalley, Scourfield, \& Greenland, 2005, p. 138, emphases removed)

\section{Excerpt 6: 'Preventing Suicide: A Neglected Social Work Research Agenda'}

Suicide is a major social and public health problem. Our review of journal publications focused on the contribution of social work research from 1980 to 2006 to knowledge for guiding suicide risk assessment, intervention and prevention. Professional social work practice, at its core, should be based on relevant and valid knowledge to guide intervention; however, research supporting evidence-based practice has been traditionally underrepresented 
in social work .... There are several practice implications that we can draw from this survey of suicide research literature produced by social workers. In their practice, social workers must understand the demographic patterns and the trends in suicide - namely that younger members of several Western countries are completing suicide at higher rates-and that, therefore, early preventive interventions with older adolescents and young adults, particularly males, must become an integral part of more coordinated suicide prevention efforts. ... Most professionals rely on their own profession's literature as their primary source of practice knowledge. Although research from other disciplines is substantial, our results suggest that social work investigators need to incorporate social work's unique concepts, perspectives and techniques to help build a scientifically developed clinical knowledge base more applicable for use by social work practitioners working with suicidal clients. (Joe \& Niedermeier, 2008, p.523f)

These two excerpts are representative of what research articles in social work look like in discussing findings or implications related to suicide and suicide prevention. The most obvious contrast with protest communication and political communication is the matter-offactness of scientific communication. The first excerpt, taken from an article reviewing research on the causes of suicidal behaviour, concentrates on the difficulty of establishing clear causal relationships. Not only can there be interaction effects between mental illness and suicidal feelings or even reversed causality, that is, suicidal feelings as a cause of mental illness. Furthermore, there is the question where to cut the causal chain: is mental illness the cause of suicide, or is it an intermediate variable between social (such as unemployment) or bio-physical factors (substance addiction, violence)? The point we want to illustrate here is that scientific observers construct suicide as a social problem with a more complex causality than protest movements or political agents. The scientific report constructs no unequivocal causes, clear villains or obvious solutions.

The second excerpt stresses that suicide is a social problem. However, for social work as a scientific discipline, this is primarily a matter of gathering scientific knowledge. Because of the self-understanding of academic social work, this knowledge needs to be applicable by practitioners. The proclaimed solution to the problem definition is hence the development of genuine social work knowledge in order to make suicide prevention more successful. Such a problem construction makes social work researchers at least partly responsible for preventing suicide. It is their responsibility to increase (evidence-based) research on suicide to provide the knowledge that practitioners working with suicidal clients need.

\section{Constructions of suicide by medicine}

Excerpt 7: 'Suicide has become less common', by a chief physician at a psychiatric clinic It is of utmost importance to emphasize that treatment with antidepressant drugs is likely to be a powerful intervention to prevent suicide. The treatment of mental illness with drugs has been regularly criticized without the enormous benefits with respect to human suffering and human life being taken into consideration. This is particularly the case with antidepressant drugs, which happen to be attacked from every possible vantage point. The most foolish arguments come, of course, from ideological organizations. Antidepressant drugs are also attacked from a narrow economic perspective even though the costs for medication constitute a very small percentage of the total healthcare budget.... One does not need any scientific 
training to understand that a decrease in suicide rates of almost one third along with a fivefold increase in the prescription of antidepressants since the 1990s indicates that medication reduces rather than increases the risk of suicide. (Isacsson, 2006)

\section{Excerpt 8: 'Suicide is not just the responsibility of psychiatry!' by a professor emeritus at a psychiatric clinic}

Suicide tends to be a medical problem, especially a problem for psychiatry. Every suicide carried out is therefore perceived as a failure of psychiatry.... if one only focuses on the care system, there is a risk that the care system will be perceived as the main party responsible and that care personnel will still feel singled out and guilty or co-responsible for what happens. ... Psychiatry has thus has been given the role of helping to redress the problems that authorities, employers, unions, courts, the mass media and the "zeitgeist" have created for individuals. Moral values in society and cultural trends constitute tremendously important background factors that affect how people feel mentally....By contrast should people working in psychiatry always account for being unable to prevent adolescents from getting drunk, taking drugs and harming themselves?....Psychiatry cannot "cure" existential unhappiness... (Jacobsson, 2010, pp. 84-85)

These excerpts from the journal of the Swedish Medical Association suggest that doctors construct suicide primarily as a medical problem to be treated with medical means. Since suicide is observed as the symptom of a diagnosed (mental) illness, the question is then how to treat suicidal patients and their mental illness. Not only does medicine claim to have the exclusive competence to judge whether a prescription of antidepressants is a viable method for preventing suicidal patients from killing themselves - it also claims to have clinical evidence on its side. In the first excerpt, this is used as a communicative device to fend off criticism from protest movements. Both excerpts differ in their punctuation of the causal chain, just like in excerpt 5 of a social work research study. While excerpt 7 only makes statements on the effects of antidepressants, excerpt 8 highlights the broader scope of suicide as a social problem: mental illness as a proximate cause of suicide ideation. Seen in that way, suicide can be prevented by treating mental illness medically. However, this is only treatment of the symptom because the diagnosis is ultimately aimed at shortcomings in contemporary society as causes of mental illness. Extrapolating this logic, suicide prevention would require solving other social problems first. As for the actors involved, the observer in excerpt 8 wants to free psychiatry from the responsibility for suicide among mentally ill people and re-establish the (functional) limits of the medical system: he argues that suicide as a social problem has been passed on by others (politics, authorities, employers etc.).

\section{Implications for research in social work}

As we have shown in the preceding analyses, suicide among people with mental illness has been constructed differently by different observers along systemic boundaries on the basis of the parameters suggested by Loseke. There seems to be consensus only in terms of the morality/cultural theme: all observers want to prevent suicide. It is thus taken for granted that suicide is a moral evil to be avoided.

In this concluding section, we want to identify some implications of the suggested 
combination of a constructionist approach to social problems using Luhmann's theory of functional differentiation for research in social work. Social problems are often treated as an unreflected mix of first- and second-order realities. Constructionists argue that social problems are claims-making activities, that is, communication (see also Loseke, 2003, p. 15), and this means second-order realities. Therefore an analysis of social problems is an analysis of communication (of a claims-making activity). The specific contribution of Luhmann's differentiation theory is that it indicates and explains societal dividing lines between such observers. Political observers will likely select and interpret information differently than scientific or medical observers.

There are at least three implications of the synthesized approach suggested for the study of social problems and for the interventions undertaken by practitioners. First, when social work research or claims-makers in social movements interpret a situation as a social problem, they respond to the first-order reality, which is identified based on certain data (for instance, the number of young people who spent the night in stairwells), with a second-order reality interpretation (poverty, homelessness, drug abuse, family violence). The interpretation, in turn, calls for and justifies a specific course of action. It is important to see that these actions undertaken are not caused by properties of first-order reality but are governed by meanings attributed to observer-independent facts, thus on the level of second-order realities. Second, controversies regularly occur in research and between different interpreters/constructors of social problems. This is partly due to a failure to distinguish between first- and second-order realities and understand how both are interconnected. There is variability in definitions and descriptions (second-order reality) and an alleged constancy in the conditions to which they are related (first-order reality). Thus variations in the descriptions of the condition must result from the social parameters - causal relations, cultural themes, people and solutions - rather than from the condition itself. Disagreements also occur as a result of the incommensurability of the perspectives of observers involved and communicative forms employed, as Luhmannian theory teaches us. Studying social problems as claims-making activities, hence as communication of different observers, helps then, for instance, to disentangle potential muddles by looking at and charting who says what, when, how and (possibly) why, when something is presented as a social problem. Third, there is a great risk to the integrity of academic social work when phenomena for which there is little or no direct knowledge are communicated - for instance by welfare state agencies or social movements - and acknowledged as being social problems. If levels of reality are not kept separate and the different perspectives of observers are not accounted for, judgments and definitions made by others could be accepted uncritically. A methodological recommendation for studying social problems is thus to account for the observer. Always ask by whom, how (with regard to Loseke's parameters), and if possible even why it is described as a social problem.

\section{References}

Author (2007)

Author (2008)

Author (2010)

Author (2011) 
Author (2012)

Author (2013)

Andersson, J. (2010). Hur är det möjligt att man kan ta sitt liv inne på en slutenvårdsavdelning? [How is it possible to take one's live inside an inpatient care?] Revansch, 30(1), 21.

Appel Nissen, M. (2010). Nye horisonter $i$ socialt arbejde: en reflektionsteori. [New horizons in social work: a reflexion theory].Copenhagen: Akademisk Forlag.

Baecker, D. (1994). Soziale Hilfe als Funktionssystem der Gesellschaft [Social help as a function system of society]. Zeitschrift für Soziologie, 23(1), 93-110.

Best, J. (Ed.). (1989). Images of Issues: Typifying Contemporary Social Problems. Hawthorne, NY: Aldine de Gruyter.

Bommes, M., \& Scherr, A. (2000). Soziologie der sozialen Arbeit [Sociology of social work]. Weinheim ;Basel: Beltz Juventa.

Carlsson, A. (2012). Proposition (Swedish Government Bill) 2012/13:So330 Suicide prevention. Stockholm.

Cohen, S. (2002[1972]). Folk Devils and Moral Panic. Oxon \& New York: Routledge.

Danermark, B., Ekström, M., Jakobsen, L., \& Karlsson, J. (2002). Explaining Society. Critical Realism in the Social Sciences. Oxon \& New York: Routledge.

Durkheim, E. (1979). Suicide. A study in sociology. New York: Free Press.

Fuchs, S. (2001). Against essentialism. Cambridge, MA: Harvard University Press.

Fuller, R., \& Myers, R. (1941). Some aspects of a theory of social problems. American Sociological Review, 6(2), 24-32.

Goode, E., \& Ben-Yehuda, N. (2009). Moral Panics. The Social Construction of Deviance (2 ed.). Chichester: Wiley.

Gould, N., \& Baldwin, M. (Eds.). (2004). Social Work, Critical Reflection, and the Learning Organization. Burlington, VT: Ashgate.

Hazelrigg, L. E. (1986). Is there a choice between constructionism and objectivism. Social Problems, 33(6), 1-13.

Healy, L. \& Link, R. (Eds.). (2012). Handbook of International Social Work: Human Rights, Development, and the Global Profession. New York: Oxford University Press.

Hellmann, K.-U. (1994). Zur Eigendynamik sozialer Probleme [On the momentum of social problems]. Soziale Probleme, 5(1), 144-167.

Holstein, J., \& Miller, G. (1993a). Reconstituting the Constructionist Program. In J. Holstein \& G. Miller (Eds.), Reconsidering Social Constructionism Debates in Social Problems Theory (pp. 241-250). Hawthorne, NY: Aldine.

Holstein, J., \& Miller, G. (Eds.). (1993b). Reconsidering Social Constructionism: Debates in Social Problems Theory. Hawthorne, NY: Aldine de Gruyter.

Houston, S. (2001). Beyond social constructionism: Critical realism and social work. British Journal of Social Work, 31(6), 845-861.

Ibarra, P., \& Kitsuse, J. (1993). Vernacular constituents of moral discourse: An interactionist proposal for the study of social problems. In J. Holstein \& G. Miller (Eds.), Reconsidering social constructionism: Debates in social problems theory (pp. 25-58). Hawthorne NY: Aldine De Gruyter.

Isacsson, G. (2006). Självmord har blivit allt ovanligare [Suicide has become less and less common]. Läkartidningen, 103(17), E24-25. 
Jacobsson, L. (2010). Självmord är inte enbart psykiatrins ansvar! [Suicide is not the responsibility of psychiatry alone!] Läkartidningen, 107(3), 84-85.

Joe, S., \& Niedermeier, D. (2008). Preventing suicide: A neglected social work research agenda. British Journal of Social Work, 38(3), 507-530.

Jönson, H. (2010). Sociala problem som perspektiv. En ansats för forskning och socialt arbete [Social Problems as Perspectives. An approach for research and social work]. Malmö: Liber.

Korpi, T., Nelson, K., \& Stenberg, S.-A. (2007). The accumulation of social problems 19742000. International Journal of Social Welfare, 16(S), S91-S104.

La Cour, A. (2002). Frivillighedens pris: en unders $\phi g$ else af Niklas Luhmanns teori om sociale systemer og dens anvendelse på området for frivilligt socialt arbejde [The price of voluntariness: an examination of Niklas Luhmann's theory of social systems and its application on the realm of voluntary social work]. Copenhagen: Copenhagen University.

Loseke, D. (2003). Thinking about social problems (2 ed.). Hawthorne, NY: Aldine Transaction.

Loseke, D., \& Best, J. (Eds.). (2011). Social Problems: Constructionist Readings. Hawthorne, NY: Aldine Transaction.

Luhmann, N. (1982). The Differentiation of Society. New York: Columbia University Press.

Luhmann, N. (1990). Die Wissenschaft der Gesellschaft [The science of society]. Frankfurt/Main: Suhrkamp.

Luhmann, N. (1997). Die Gesellschaft der Gesellschaft [The society of society]. Frankfurt/Main: Suhrkamp.

Luhmann, N. (2000). Die Politik der Gesellschaft [The polity of society]. Frankfurt/Main: Suhrkamp.

Luhmann, N. (2005). Der medizinische Code [The medical code]. In N. Luhmann (Ed.), Soziologische Aufklärung 5 [Sociological enlightenment] (pp. 176-188). Wiesbaden: VS Verlag.

Merten, R. (Ed.). (2000). Systemtheorie Sozialer Arbeit [Systems theory of social work]. Opladen: Leske+Budrich.

Merton, R. K., \& Nisbet, R. (Eds.). (1971). Contemporary social problems. New York: Harcourt Brace Jovanovich.

Mik-Meyer, N., \& Villadsen, K. (2013). Power and Welfare: Understanding Citizens' Encounters with State Welfare. New York: Routledge.

Moe, S. (2003). Den moderne hjelpens sosiologi. Velferd i systemteoretisk perspektiv [The sociology of modern help. Welfare in a systems-theoretical perspective]. Sandnes: Apeiros Forlag.

Payne, M. (1999). Social Construction in Social Work Action and Practice. In A. Jokinen, K. Juhila \& T. Pösö (Eds.), Constructing Social Work Practices (pp. 25-65). Aldershot: Ashgate.

Payne, M. (2005a). Modern Social Work Theory. Basingstoke: Palgrave Macmillan.

Payne, M. (2005b). The Origins of Social Work. Continuity and change. Basingstoke: Palgrave Macmillan.

Rubington, E., \& Weinberg, M. (2010). The Study of Social Problems: Seven Perspectives (7 ed.). Oxford: Oxford University Press. 
Saake, I. (2003). Die Performanz des Medizinischen. Zur Asymmetrie der Arzt-PatientenInteraktion [The performance of medicine. On the asymmetry of the doctor-patient interaction]. Soziale Welt, 54(4), 429-459.

Scherr, A. (1999). Transformations in social work: From help towards social inclusion to the management of exclusion. European Journal of Social Work, 2(1), 15-25.

Smalley, N., Scourfield, J., \& Greenland, K. (2005). Young People, Gender and Suicide: A Review of Research on the Social Context. Journal of Social Work, 5(2), 133-154.

Snow, D., \& Benford, R. (1988). Ideology, frame resonance, and participant mobilization. International Journal of Social Movement Research, 1, 197-218.

SOU [Swedish Government Official Reports]. (2010). SOU 2010:45 Händelseanalyser vid självmord inom hälso- och sjukvården och socialtjänsten [Event analyses of suicides in healthcare and social service]. Stockholm: Fritzes offentliga publikationer.

Spector, M., \& Kitsuse, J. (1987 [1977]). Constructing social problems. Hawthorne NY: de Gruyter.

Staub-Bernasconi, S. (2010). Soziale Arbeit und soziale Probleme [Social work and social propblems]. In W. Thole (Ed.), Grundriss Soziale Arbeit. Ein einführendes Handbuch [Compendium social work: an introductory handbook] (pp. 267-282). Wiesbaden: VS-Verlag.

Trevett, J. (2011). Statistik som skrämmer [Statistics that frightens]. Revansch, 31(4), 2.

Trevithick, P. (2007). Social Work Skills. A Practice Handbook. Glasgow: Open University Press.

Troyer, R. J. (1992). Some consequences of contextual constructionism. Social Problems, 39(1), 35-37.

Villadsen, K. (2008). Polyphonic welfare: Luhmann's systems theory applied to modern social work. International Journal of Social Welfare, 17(1), 65-73.

Watzlawick, P. (1984). The invented reality. How do we know what we believe we know? Contributions to constructivism. New York: Norton.

Willke, H. (1992). Ironie des Staates [Irony of the state]. Frankfurt/Main: Suhrkamp.

Wirth, J. (2009). The Function of Social Work. Journal of Social Work, 9(4), 405-419.

Woolgar, S., \& Pawluch, D. (1985). Ontological gerrymandering: The anatomy of social problems explanations. Social Problems, 32(3), 214-227. 